Journal An-Nafs: Kajian Penelitian Psikologi

http://ejournal.iai-tribakti.ac.id/index.php/psikologi

e-ISSN: 2549-6166

p-ISSN: 2528-0600

\title{
KEPRIBADIAN NARAPIDANA DALAM TINJAUAN MODEL BIG FIVE PERSONALITY
}

\author{
Tania Mayendry ${ }^{1}$, Ahmad Hidayat ${ }^{2}$, Juliarni Siregar ${ }^{3}$ \\ 1tmayendry27@gmail.com, 2ahmadhidayat@psy.uir.ac.id, \\ 3juliarnisiregar@yahoo.com \\ Universitas Islam Riau \\ https://doi.org/10.33367/psi.v4i2.816
}

\begin{abstract}
Abstrak
Tujuan penelitian ini adalah untuk mengetahui gambaran kepribadian narapadina di Bangkinang. Penelitian ini melibatkan 288 orang narapidana yang dipilih dengan menggunakan teknik cluster random sampling 2 tahap. Alat ukur yang digunakan yaitu Big Five Inventory (BFI) oleh McCrae dan Costa dan telah di adaptasi oleh Ramdhani (2012) yang terdiri dari 44 aitem. Analisis yang digunakan yaitu analisis statistik deskriptif. Hasil penelitian ini menunjukkan bahwa dari kelima faktor ditemukan faktor kepribadian yang paling menonjol yaitu agreeableness dengan nilai mean 3,83 dan yang paling rendah yaitu faktor kepribadian neuroticsm dengan nilai mean 2,98. Jika ditinjau dari rentang usia ditemukan bahwa untuk usia 20-40 tahun dan 40-65 tahun sama-sama menonjol pada faktor kepribadian agreeableness untuk kedua rentang usia tersebut dengan nilai mean 3,82 dan 3,86 sedangkan faktor kepribadian dengan mean terendah adalah pada faktor neuroticsm dengan nilai mean 3,00 dan 2,98. Analisis berdasarkan jenis kejahatan yaitu narkoba dan kriminalitas juga menunjukkan bahwa faktor kepribadian yang paling menonjol pada kedua jenis kejahatan ini adalah faktor agreeableness dengan nilai 3,90 dan 3,68 untuk jenis kejahatan kriminalitas. Analisis berdasarkan jenis kejahatan yaitu narkoba dan kriminalitas menunjukkan bahwa kedua jenis kejahatan sama-sama memiliki nilai mean terendah pada faktor kepribadian neuroticsm dengan nilai mean 2,90 dan 3,15.
\end{abstract}

Kata Kunci: Kepribadian, Big Five Personality, Narapidana 
Tania Mayendry, Dkk | Kepribadian Narapidana

\begin{abstract}
The purpose of this study was to describe the personality of prisoners in Bangkinang's prison. The personality trait was assessed by Indonesian Big Five Inventory (BFI) that has been adapted by Ramdhani (2012) which consists of 44 items. Descriptive statistical analysis was used in this research. The result of this study shows that the highest mean score of personality trait is agreeableness (3.83) while neuroticsm has the lowest mean score (2.98). Based on the age range, all of the age range of the prisoner indicates that the most common trait is agreeableness (mean score 3.82 for 20-40 years old and 3.86 for 40-65 years old) while the lowest neuroticsm (mean score 3.00 for 20-40 years old and 2.98 for 40-65 years old). Analysis based on the type of offences shosw that the drugs and crime prisoners have agreeableness as the most trait (mean score 3.90 and 3.68) while the neuroticsm is the lowest (mean score 2.90 and 3.15).
\end{abstract}

Keywords: Personality, Big Five Personality, Inmates

\title{
Pendahuluan
}

Melakukan tindak kejahatan saat ini sudah banyak ditemui di kehidupan sehari-hari. Individu di dalam masyarakat dapat dengan mudahnya menyakiti individu lain, berperilaku seenaknya seakan tidak ada aturan yang berlaku sebagai resiko dari perbuatannya. Individu yang diberikan sanksi kurungan penjara biasa disebut narapidana. Sudirohusodo (2002) mengatakan bahwa narapidana adalah seseorang yang telah ditetapkan secara hukum bersalah dan dibina pada lembaga pemasyarakatan. Narapidana akan menghabiskan hidupnya di dalam penjara sesuai dengan hukuman yang didapatnya.

Bangkinang merupakan salah satu kabupaten di Provinsi Riau yang secara statistik menunjukkan peningkatan jumlah narapidana secara signifikan setiap tahunnya. Peningkatan ini tidak diikuti oleh penambahan jumlah fasilitas seperti jumlah sel tahanan. Dapat di lihat pada tabel berikut ini:

114 | Journal An-nafs: Vol. 4 No. 2 Desember 2019 
Tania Mayendry, Dkk | Kepribadian Narapidana

Tabel 1

Jumlah Narapidana Dewasa

\begin{tabular}{|c|c|c|c|}
\hline \multicolumn{4}{|c|}{ Narapidana } \\
\hline Tahun & $\begin{array}{c}\text { Dewasa } \\
\text { Laki-laki }\end{array}$ & $\begin{array}{c}\text { Dewasa } \\
\text { Perempuan }\end{array}$ & $\begin{array}{c}\text { Total } \\
\text { Dewasa }\end{array}$ \\
\hline $\mathbf{2 0 1 5}$ & 406 & 3 & 409 \\
\hline $\mathbf{2 0 1 6}$ & 559 & 19 & 578 \\
\hline $\mathbf{2 0 1 7}$ & 847 & 25 & 872 \\
\hline $\mathbf{2 0 1 8}$ & 1035 & 28 & 1063 \\
\hline
\end{tabular}

Berdasarkan tabel di atas dapat di lihat bahwa total narapidana dewasa di Bangkinang meningkat secara signifikan setiap tahunnya, namun peningkatan yang signifikan itu hanya terjadi pada jumlah narapidana dewasa laki-laki. Pada tahun 2015 hingga tahun 2016 terjadi peningkatan sebanyak 153 orang. Pada tahun 2016 hingga tahun 2017 peningkatan terjadi sebanyak 288 orang dan pada tahun 2017 hingga 2018 terjadi peningkatan sebanyak 188 orang.

Peningkatan jumlah narapidana yang terjadi di Bangkinang dapat disebabkan oleh faktor eksternal dan internal. Faktor eksternal yang umumnya berpengaruh terhadap tindakan kejahatan adalah faktor lingkungan dan ekonomi (Kartono, 2007; Koranti \& Purwani, 2014). Namun, menurut Suharsoyo (2014) selain faktor lingkungan yang menjadi salah satu penyebab kejahatan terdapat juga faktor kelalaian korban, ikatan sosial dan faktor perkembangan teknologi. Sedangkan untuk faktor internal terdapat beberapa faktor yang menjadi penyebab kejahatan yaitu daya emosional, rendahnya mental, kejiwaan, umur, jenis kelamin, pendidikan serta keyakinan (Kartono, 2007; Koranti \& Purwani, 2014; Suharsoyo; 2014).

Terdapat banyak penelitian yang telah dilakukan untuk mengetahui faktor eksternal penyebab terjadinya tindakan kejahatan, seperti penelitian yang dilakukan oleh Nur'artavia (2017) yang meneliti mengenai pengaruh penyalahgunaan napza. dalam penelitiannya didapatkan bahwa lingkungan pertemanan 
sekolah maupun lingkungan tempat tinggal merupakan salah satu faktor penyebab penyalahgunaan napza.

Selanjutnya penelitian yang dilakukan oleh (Lumenta, Kekenusa \& Hatidja, 2012; Pasiza, Nugroho \& Faisal, 2014; Ichsan, 2016) menunjukkan bahwa faktor kepadatan penduduk, tingkat pengangguran dan kemiskinan merupakan salah satu faktor tidak langsung yang mempengaruhi penyebab kriminalitas di Indonesia. Lain halnya dengan penelitian yang dilakukan oleh Alifi (2016) mengenai perilaku kriminal di Kabupaten Pekalongan, Jawa Tengah yang menunjukkan bahwa penyebab seseorang melakukan tindak kejahatan dikarenakan oleh faktor pendidikan yang rendah dan lingkungan yang kurang baik.

Terjadinya peningkatan jumlah narapidana yang cukup signifikan di Bangkinang dapat disebabkan oleh beberapa faktor yang saling berhubungan. Faktor-faktornya dapat berupa faktor eksternal dan faktor internal. Faktor eksternal seperti yang sudah dipaparkan di atas dapat disebabkan oleh faktor ekonomi, lingkungan, dan lain-lain. Seperti yang telah dipaparkan di atas, dapat dilihat bahwa terdapat banyak penelitian mengenai faktor penyebab kejahatan di Indonesia yang hanya berfokus pada faktor-faktor eksternal. Sedangkan, faktor internal berupa kepribadian masih sedikit diteliti, oleh karena itu peneliti ingin mengetahui penyebab tindak kejahatan berdasarkan faktor internal yang dapat disebabkan oleh genetik atau keturunan untuk dapat mencegah terjadinya peningkatan tindak kejahatan.

Genetik atau keturunan yang secara alami terdapat pada setiap individu dan secara lahiriah dibawa oleh setiap individu tersebut, dimana faktor terbentuknya kepribadian itu terbentuk secara turun temurun dari orang tua mereka sendiri. Berdasarkan hal tersebut dapat dilihat bahwa keturunan atau genetik merupakan salah satu faktor penting untuk menentukan kepribadian seorang individu (Mastuti, 2005).

Feist dan Feist (2008) mengatakan bahwa Karakter yang tidak dapat dirubah dan khas dalam perilaku seseorang serta hanya dimiliki satu individu merupakan pengertian dari 
kepribadian (personality). Trait atau sifat merupakan salah satu pendekatan untuk melihat kepribadian seseorang yang memberikan kontribusi untuk perbedaan individu satu dengan yang lainnya dalam berperilaku, konsistensi dalam berperilaku dan stabilitas perilaku dalam setiap situasi yang dihadapi individu itu sendiri.

Penggunaan big five personality sebagai alat ukur kepribadian sudah banyak diteliti oleh berbagai peneliti diseluruh dunia. Ramdhani (2014) melakukan penelitian uji konfirmatori pada adaptasi bahasa dan budaya inventori big five dan mendapatkan hasil reliabilitas yang cukup baik pada setiap dimensi. John dan Srivastava (1999) menyatakan bahwa 44 aitem big five personality dapat menggambarkan lima faktor kepribadian secara sempurna dengan demikian dapat dilihat bahwa penggunaan big five personality sebagai alat ukur kepribadian pada individu dapat digunakan.

Feist dan Feist (2010) menyatakan big five adalah salah satu kepribadian yang dapat menjelaskan dan memprediksi perilaku. Pendekatan yang digunakan dalam psikologis untuk melihat kepribadian manusia melalui trait yang tersusun dalam lima buah domain kepribadian yang telah dibentuk dengan menggunakan analisis faktor. Lima faktor tersebut adalah conscientiousness (kenuranian), extraversion (keterbukaan), agreeableness (kebersetujuan), neuroticsm (kecemasan) dan openness to experience (terbuka kepada pengalaman).

Kepribadian dipengaruhi oleh faktor keturunan dan faktor lingkungan sehingga kepribadian dapat menjadi salah satu faktor pendukung yang kuat bagi seseorang untuk melakukan kejahatan karena kepribadian tidak dapat dirubah dengan mudah. Dari kelima dimensi yang telah dipaparkan diatas, setiap manusia cenderung memiliki salah satu faktor kepribadian sebagai faktor yang paling dominan bagi seorang individu untuk melakukan suatu tindakan perbuatan. 
Tania Mayendry, Dkk | Kepribadian Narapidana

\section{Metode Penelitian}

Penelitian ini merupakan penelitian deskriptif kuantitatif yang memberikan penjelasan terhadap fenomena berdasarkan data yang telah di analisa. Populasi merupakan kelompok yang memiliki karakteristik sesuai dengan tujuan penelitian (Bungin, 2011). Populasi penelitan ini adalah narapidana laki-laki Bangkinang. Sampel adalah sebagian dari populasi yang memiliki karakteristik sesuai dengan populasi. Sampel dalam penelitian ini berjumlah 288 orang yang didapatkan dengan menggunakan teknik slovin dengan taraf signifikansi 95\% dan tingkat kesalahan $5 \%$.

Bangkinang memiliki 8 blok dengan jumlah sel yang berbeda pada masing-masing blok. Oleh karena itu peneliti melakukan teknik pengambilan sampel dalam penelitian ini dengan menggunakan teknik cluster random sampling 2 tahap. Pada tahap pertama peneliti melakukan random terhadap blok yang berjumlah 8 blok yaitu blok A hingga blok $\mathrm{H}$ dan mendapatkan 5 blok secara random. Selanjutnya, pada tahap kedua peneliti melakukan random sel terhadap blok yang sudah terpilih sebelumnya dan peneliti mendapatkan 3 sel pada masingmasing blok yang terpilih.

Alat ukur yang digunakan dalam penelitian ini adalah skala kepribadian big five personality yang telah di adaptasi oleh Ramdhani (2012) dengan menggunakan model skala Likert, dimana validitas dalam penelitian ini menggunakan metode confirmatory factor analysis (CFA) model lima faktor fit.

Reliabilitas skala dalam penelitian ini menunjukkan nilai Alpha Cronbach yaitu faktor openness to experience sebesar 0,77; conscientiousness sebesar 0,73 ; extraversion sebesar 0,73; agreeableness sebesar 0,72; dan neuroticsm sebesar 0,79. Hasil ini tidak jauh berbeda dengan hasil reliabilitas pada penelitian Ramdhani (2012) yaitu, conscientiousness (kenuranian) 0.78, extraversion (keterbukaan) 0.73, agreeableness (kebersetujuan) 0.76 , neuroticsm (kecemasan) 0.74 dan openness to experience (terbuka kepada pengalaman) 0.79 .

118 | Journal An-nafs: Vol. 4 No. 2 Desember 2019 
Analisis yang digunakan dalam penelitian ini adalah analisis statistik deskriptif dengan melihat nilai mean dan nilai standar deviasi.

\section{Paparan Hasil}

Hasil penelitian ini menunjukkan bahwa dari kelima faktor ditemukan faktor kepribadian yang paling menonjol yaitu agreeableness dengan nilai mean 3,83 dan yang paling rendah yaitu faktor kepribadian neuroticsm dengan nilai mean 2,98. Jika ditinjau dari rentang usia ditemukan bahwa untuk usia 20-40 tahun dan 40-65 tahun sama-sama menonjol pada faktor kepribadian agreeableness untuk kedua rentang usia tersebut dengan nilai mean 3,82 dan 3,86 sedangkan faktor kepribadian dengan mean terendah adalah pada faktor neuroticsm dengan nilai mean 3,00 dan 2,98. Analisis berdasarkan jenis kejahatan yaitu narkoba dan kriminalitas juga menunjukkan bahwa faktor kepribadian yang paling menonjol pada kedua jenis kejahatan ini adalah faktor agreeableness dengan nilai 3,90 dan 3,68 untuk jenis kejahatan kriminalitas. Analisis berdasarkan jenis kejahatan yaitu narkoba dan kriminalitas menunjukkan bahwa kedua jenis kejahatan sama-sama memiliki nilai mean terendah pada faktor kepribadian neuroticsm dengan nilai mean 2,90 dan 3,15.

\section{Pembahasan}

Dengan menggunakan analisis deskriptif, menunjukkan bahwa analisis mean mendapatkan nilai mean skor tertinggi pada faktor agreeableness dengan nilai 3,83 dan mean skor terendah terletak pada faktor neuroticsm dengan nilai 2,98 yang dapat di lihat pada tabel di bawah ini: 
Tania Mayendry, Dkk | Kepribadian Narapidana

Tabel 2

Deskripsi Data Penelitian Secara Umum

\begin{tabular}{|l|c|c|}
\hline \multicolumn{1}{|c|}{ Big Five } & Mean & SD \\
\hline Opennes to experience & 3,42 & 0,45 \\
\hline Conscientiousness & 3,49 & 0,51 \\
\hline Extraversion & 3,64 & 0,54 \\
\hline Agreeableness & 3,83 & 0,60 \\
\hline Neuroticsm & 2,98 & 0,47 \\
\hline
\end{tabular}

Berikut tabel berdasarkan jenis kejahatan:

Tabel 3

Deskripsi Data Berdasarkan Jenis Kejahatan

\begin{tabular}{|l|c|c|c|c|c|}
\hline \multicolumn{1}{|c|}{ Big Five } & \multicolumn{2}{|c|}{$\begin{array}{c}\text { Skor empirik } \\
\text { sampel } \\
\text { dengan jenis } \\
\text { kejahatan } \\
\text { narkoba }\end{array}$} & \multicolumn{2}{c|}{$\begin{array}{c}\text { Skor empirik } \\
\text { sampel } \\
\text { dengan jenis } \\
\text { kejahatan } \\
\text { kriminalitas }\end{array}$} & \\
\cline { 2 - 6 } & Mean & SD & SD & Mean & Sig \\
\hline $\begin{array}{l}\text { Opennes to } \\
\text { experience }\end{array}$ & 3,45 & 0,45 & 0,43 & 3,35 & 0,059 \\
\hline Conscientiousness & 3,55 & 0,49 & 0,52 & 3,37 & 0,004 \\
\hline Extraversion & 3,70 & 0,49 & 0,62 & 3,52 & 0,006 \\
\hline Agreeableness & 3,90 & 0,55 & 0,65 & 3,68 & 0,002 \\
\hline Neuroticsm & 2,90 & 0,49 & 0,39 & 3,15 & 0,000 \\
\hline
\end{tabular}

Apabila dilakukan perbandingan nilai mean antara faktorfaktor pada jenis kejahatan narkoba dan kriminalitas dengan menggunakan $t$-test maka didapatkan hasil bahwa tidak terdapat perbedaan mean skor yang signifikan di antara jenis kejahatan narkoba dan kriminalitas pada faktor openness to experience dengan signifikansi $(p)$ sebesar 0,059 $(p>0,05)$. Sedangkan untuk analisis mean skor pada faktor-faktor lain yaitu terdapat perbedaan mean skor yang signifikan di antara mean masingmasing faktor pada jenis kejahatan narkoba dan kriminalitas.

Hasil analisis menggunakan t-test untuk faktor kepribadian conscientiousness mendapatkan nilai dengan signifikan $(p)$ sebesar $0,004 \quad(p<0,05)$. Faktor kepribadian 
extraversion memiliki nilai dengan signifikansi $(p)$ sebesar 0,006 $(p<0,05)$. Faktor kepribadian agreeableness memiliki nilai dengan signifikansi $(p)$ sebesar $0,002 \quad(p<0,05)$ dan untuk faktor kepribadian neuroticsm memiliki nilai dengan signifikansi $(p)$ sebesar 0,000 $(p<0,05)$. Hasil analisis $t$-test tersebut membuktikan bahwa terdapat perbedaan mean skor yang signifikan di antara jenis kejahatan narkoba dan kriminalitas pada faktor-faktor tersebut.

Pada tabel tersebut dapat dilihat bahwa nilai mean antara faktor-faktor kepribadian pada kejahatan narkoba memiliki nilai yang berbeda-beda. Kedua jenis kejahatan tersebut sama-sama memiliki mean skor tertinggi pada faktor agreeableness dengan nilai mean 3,90 untuk jenis kejahatan narkoba dan nilai mean 3,68 untuk jenis kejahatan kriminalitas. Sedangkan untuk mean skor terendah dari kedua jenis kejahatan tersebut sama-sama terletak pada faktor neuroticsm dengan nilai mean 2,90 untuk jenis kejahatan narkoba dan nilai mean 3,15 untuk jenis kejahatan kriminalitas.

Oleh karena pada faktor kepribadian openness to experience tidak terdapat perbedaan mean skor maka kondisi sampel pada jenis kejahatan narkoba dan kriminalitas dianggap sama, sedangkan pada faktor kepribadian conscientiousness, extraversion, agreeableness dan neuroticsm terdapat perbedaan mean skor yang signifikan pada kondisi sampel pada kedua jenis kejahatan tersebut. berikut adalah tabel berdasarkan rentang usia:

Tabel 4

Deskripsi Data Berdasarkan Rentang Usia

\begin{tabular}{|l|c|c|c|c|c|}
\hline \multicolumn{1}{|c|}{ Big Five } & \multicolumn{2}{|c|}{$\begin{array}{c}\text { Skor empirik } \\
\text { sampel } \\
\text { dengan } \\
\text { rentang usia } \\
\text { 20-40 tahun }\end{array}$} & $\begin{array}{c}\text { Skor empirik } \\
\text { sampel dengan } \\
\text { rentang usia } \\
\mathbf{4 0 - 6 5} \text { tahun }\end{array}$ & t-test \\
\cline { 2 - 6 } & Mean & SD & SD & Mean & Sig \\
\hline $\begin{array}{l}\text { Opennes to } \\
\text { experience }\end{array}$ & 3,42 & 0,45 & 3,40 & 0,47 & 0,782 \\
\hline Conscientiousness & 3,48 & 0,52 & 3,53 & 0,44 & 0,467 \\
\hline
\end{tabular}

Journal An-nafs: Vol. 4 No. 2 Desember 2019|121 
Tania Mayendry, Dkk | Kepribadian Narapidana

\begin{tabular}{|l|l|l|l|l|l|}
\hline Extraversion & 3,64 & 0,54 & 3,60 & 0,60 & 0,674 \\
\hline Agreeableness & 3,82 & 0,60 & 3,86 & 0,56 & 0,600 \\
\hline Neuroticsm & 3,00 & 0,48 & 2,98 & 0,54 & 0,782 \\
\hline
\end{tabular}

Berdasarkan tabel di atas dapat dilihat bahwa mean skor tertinggi pada rentang usia 20-40 tahun berada pada faktor agreeableness dengan nilai 3,82 dan mean skor terendah pada faktor neuroticsm dengan nilai 3,00. Pada rentang usia 40-65 juga memiliki nilai mean skor tertinggi pada faktor agreeableness dengan nilai 3,86 dan mean skor terendah pada faktor neuroticsm dengan nilai 2,98.

Jika melihat hasil perbandingan antara nilai mean skor rentang usia 20-40 tahun dengan usia 40-65 tahun pada masingmasing faktor dengan menggunakan analisis $t$-test $(p>0,05)$ dapat dilihat bahwa tidak terdapat perbedaan mean skor yang signifikan di antara nilai mean pada masing-masing faktor. Jadi, dapat disimpulkan bahwa kelima faktor tersebut dianggap memiliki kondisi sampel yang sama apabila dilihat dari kedua rentang usia.

Hasil penelitian ini menunjukkan bahwa faktor kepribadian berdasarkan teori big five personality yang paling menonjol pada narapidana di Bangkinang baik secara umum, berdasarkan jenis kejahatan maupun berdasarkan rentang usia berada pada faktor kepribadian agreeableness. McCrae dan Costa (dalam Feist \& Feist, 2008) mengambarkan bahwa karakteristik individu yang memiliki skor tinggi pada faktor kepribadian agreeableness pada umumnya memiliki karakteristik mudah percaya dan penurut.

Narapidana secara keseluruhan memiliki mean skor tertinggi dengan nilai 3,83 pada faktor agreeableness yang berarti memiliki kepribadian mudah percaya dan penurut. Koentjoro (2013) mengatakan bahwa personalitiy traits berasosiasi dengan kejahatan dan kenakalan. Personality traits tersebut adalah tingkat kemasakan, ketidak mampuan membuat konsep, kurang kasih sayang, kurang perhatian keluarga, tidak mampu memainkan peran, dan lain-lain.

122 | Journal An-nafs: Vol. 4 No. 2 Desember 2019 
Hal ini sejalan dengan penelitian ini yang menunjukkan kepribadian mudah percaya dan penurut yang paling menonjol dimiliki oleh narapidana. Individu dengan kepribadian yang penurut dan mudah percaya pada umumnya tidak mampu membuat konsep atas dirinya sendri dan juga tidak mampu untuk memainkan peran dalam hidupnya sehingga cenderung untuk menuruti perintah yang diberikan kepadanya tanpa memikirkan sebab akibat dari perbuatannya tersebut.

Apabila melihat analisis mean pada narapidana berdasarkan jenis kejahatan narkoba menunjukkan bahwa nilai rata-rata skor yang paling tinggi berada di faktor agreeableness dengan nilai mean 3,90 yang berarti memiliki karakteristik kepribadian mudah percaya dan penurut. Nur'artavia (2017) dalam penelitiannya mengenai karakteristik penyalahgunaan napza mengatakan bahwa penyalahgunaan napza terjadi karena pengguna ingin mengikuti pola hidup kelompoknya sehingga akan mengikuti apa yang dilakukan kelompoknya. Lingkungan pertemanan sekolah maupun tempat tinggal juga merupakan salah satu penyebab dalam menyalahgunakan napza.

Hasil penelitian tersebut sejalan dengan hasil penelitian ini yang menunjukkan jenis kejahatan narkoba yang cenderung memiliki karakteristik yang mudah percaya serta penurut apabila berada di lingkungan pertemanan sekolah maupun tempat tinggal yang salah akan memiliki kemungkinan yang besar untuk melakukan penyalahgunaan napza karena ingin mengikuti apa yang dilakukan oleh kelompoknya.

Mean skor tertinggi yang dimiliki narapidana dengan jenis kejahatan kriminalitas terletak pada faktor kepribadian agreeableness dengan nilai 3,68 yang berarti memiliki kepribadian mudah percaya dan penurut. Canter (2010) dalam bukunya mengatakan bahwa studi kasus di penjara Inggris menemukan bahwa para kriminal pada umumnya adalah orang-orang yang mudah percaya tentang sesuatu di dalam hidup mereka. Canter juga mengatakan bahwa kriminalitas terjadi karena kurangnya kesadaran individu dalam melakukan sesuatu. 
Tania Mayendry, Dkk | Kepribadian Narapidana

Hal tersebut sejalan dengan hasil penelitian ini yang menunjukkan bahwa narapidana jenis kejahatan kriminalitas memiliki karakter kepribadian yang mudah percaya dan penurut. Individu yang mudah percaya dan penurut biasanya akan dengan mudah melakukan suatu pelanggaran dikarenakan kurangnya kesadaran dalam melakukan sesuatu.

Selanjutnya adalah nilai mean kepribadian narapidana berdasarkan rentang usia 20-40 tahun dan 40-65 tahun. Analisis nilai mean pada kedua rentang usia ini memiliki kategori nilai mean yang tinggi pada agreeableness. Skor yang tinggi pada faktor agreeableness memiliki karakteristik kepribadian mudah percaya dan penurut menurut McCrae dan Costa (dalam Feist \& Feist, 2008).

McCrae dan Costa (dalam Feist \& Feist, 2008) mengatakan bahwa kepribadian Lima-faktor menunjukkan sejumlah permanensi dalam usia, yaitu artinya orang dewasa diluar penyakit Alzheimer cenderung mempertahankan struktur kepribadian yang sama ketika usia mereka bertambah. Ini menunjukkan bahwa tidak ada perbedaan sifat kepribadian pada usia 20-40 tahun dan 40-65 tahun. Hal tersebut sesuai dengan hasil penelitian ini yaitu memiliki mean skor yang tinggi pada faktor kepribadian agreeableness jika ditinjau dari kedua rentang usia.

Rocque, Posick dan Hoyle (2015) dalam penelitiannya mengatakan bahwa usia adalah salah satu faktor dari perilaku kriminal. Pada masa remaja pelanggaran dilakukan untuk mengikuti kelompok sebaya, sedangkan pada masa dewasa mereka percaya bahwa melakukan pelanggaran menjadi hal wajar untuk memenuhi kebutuhan dalam kehidupan. Hal ini sesuai dengan hasil penelitian yang menunjukkan bahwa pada kedua rentang usia yang berada di masa dewasa awal dan dewasa tengah pada narapidana memiliki karakteristik kepribadian mudah percaya dan penurut yang berarti cenderung untuk melakukan berbagai hal untuk memenuhi kebutuhan hidup mereka.

124 | Journal An-nafs: Vol. 4 No. 2 Desember 2019 
Jika dilihat pada hasil penelitian ini menunjukkan bahwa kepribadian narapidana berdasarkan teori big five personality memiliki nilai mean yang terendah pada faktor neuroticsm baik pada narapidana secara umum, narapidana berdasarkan jenis kejahatan ataupun narapidana berdasarkan rentang usia. McCrae dan Costa (dalam Feist \& Feist, 2008) menggambarkan bahwa neuroticsm yang rendah berarti memiliki karakteristik kepribadian yang tenang, rileks, tidak emosional, memiliki daya tahan terhadap stress, puas terhadap diri sendiri dan merasa aman.

Mosaku, dkk (2013) yang juga mendapatkan hasil mean yang rendah pada faktor neuroticsm pada kepribadian narapidana di Nigeria. Koentjoro (2013) mengatakan bahwa salah satu karakter kriminal adalah egosentris yaitu berorientasi kepada dirinya sendiri, dan miskin emosi. Canter (2010) mengatakan bahwa pada abad ke-20 ini kriminal pada dasarnya tumbuh dari keluarga yang tidak mengajarkan anak-anak mereka untuk menunda kepuasan. Penelitian ini sejalan dengan hasil dan teori diatas, yang menyebutkan bahwa salah satu karakteristik kriminal adalah individu yang egosentris, tidak emosional dan cepat puas terhadap diri sendiri.

Poulose (2006) mengatakan bahwa salah satu ciri kriminal adalah orang-orang dengan gangguan psikopat. Orangorang dengan gangguan psikopat biasanya memiliki sifat yang menawan dan disukai banyak orang. Apabila psikopat diketahui tengah berbohong, maka ia akan dengan tulus dan menyesal berjanji tidak akan mengulangi kesalahannya namun pada kenyataannya ia hanya akan terus berbohong. Psikopat juga pada umumnya memiliki sifat egosentris.

Hal tersebut berarti bahwa orang dengan gangguan psikopat tidak akan mudah terkena stres, karena ia merasa tenang dengan berbohong dan akan terus merasa puas dengan kebohongannya tersebut. Hasil penelitian ini juga menunjukkan bahwa salah satu karakteristik kepribadian neuroticsm adalah 
Tania Mayendry, Dkk | Kepribadian Narapidana

individu yang memiliki daya tahan terhadap stress, tenang, dan puas akan diri sendiri.

\section{Simpulan}

Berdasarkan hasil analisis mean dari faktor kepribadian berdasarkan teori big five personality dapat ditarik beberapa kesimpulan, yaitu narapidana di Lapas Kelas II B Bangkinang secara umum memiliki mean tertinggi pada faktor kepribadiam agreeableness dengan mean skor 3,83 dan mean terendah pada faktor kepribadian neuroticsm dengan mean skor 2,98. Narapidana dengan jenis kejahatan narkoba dan kriminalitas sama-sama memiliki mean skor tertinggi pada faktor kepribadian agreeableness dengan nilai 3,90 untuk jenis kejahatan narkoba dan 3,68 untuk jenis kejahatan kriminalitas. Sedangkan untuk mean skor terendah pada kedua jenis kejahatan terdapat pada faktor kepribadian neuroticsm dengan nilai 2,90 dan 3,15. Narapidana dengan rentang usia 20-40 tahun memiliki nilai mean 3,82 dan rentang usia 40-65 tahun memiliki nilai mean 3,86. Kedua rentang usia ini sama-sama memiliki mean tertinggi pada faktor agreeableness dan memiliki nilai terendah pada faktor neuroticsm dengan nilai mean 3,00 untuk rentang usia 20-40 tahun dan nilai 2,98 untuk usia 40-65 tahun.

\section{Saran}

Berdasarkan hasil penelitian tersebut, maka dapat dikemukakan saran yaitu peneliti berharap Lapas Kelas II B Bangkinang dapat memberikan intervensi, konseling, dan terapi kelompok berdasarkan jenis kepribadian yang dimiliki untuk dapat mengurangi peningkatan narapidana yang terus terjadi, seerti memberikan kegiatan atau program seperti kerohanian atau keagamaan, penanaman nilai moral dan etika, pengembangan kreativitas sesuai dengan minat, dan kegiatan kelompok yang dapat membentuk rasa saling tolong menolong.

Bagi peneliti yang berminat untuk melakukan penelitian yang sama dengan penelitian ini, disarankan untuk memperluas 
Tania Mayendry, Dkk | Kepribadian Narapidana

variasi populasi dengan meneliti narapidana dari jenis kelamin baik pria dan wanita serta anak-anak. Peneliti lain juga disarankan untuk meminimalisir faktor-faktor yang dapat merusak data penelitian. 
Tania Mayendry, Dkk | Kepribadian Narapidana

\section{Daftar Pustaka}

Alifi. M. (2016). Perilaku Kriminal Pada Pemuda Di Kecamatan Kajen Kabupaten Pekalongan Jawa Tengah. Universitas Negeri Semarang.

Canter. D. (2010). Forensic Psychology. New York: Oxford University Press

Feist. J. \& Feist. G. J. (2008). Theories of Personality. Edisi 6. Yogyakarta: Pustaka Pelajar

Feist. J. \& Feist. G. J. (2010). Teori Keprbiadian. Edisi 7. Jakarta: Penerbit Salemba

Ichsan. P.R.N. (2016). Pengaruh Faktor Sosial Ekonomi Terhadap Tingkat Kriminalitas Di Provinsi Sumatera Utara. Universitas Airlangga

John. O.P., \& Srivasta. S. (1999). The Big Five Trait Taxonomy: History, Measurement, And Theoretical Perspectives, In. L.A. Pervin \& O.P. John (Eds), Handbook of Personality: Theory and Research, 2. New York: Guilford Press.

Kartono. K. (2007). Psikologi Anak. Bandung: Mandar Maju.

Koentjoro. (2013). Kriminologi Dalam Perspektif Psikologi Sosial. Yogyakarta: Universitas Gadjah Mada.

Koranti. K., \& Purwani. W. (2014). Kajian Sosial-Ekonomi Dalam Menganalisis Faktor Penyebab Tindak Kriminal Terhadap Wanita Di Era Globalisasi. Economics \& Business Research Festival.

Lumenta. C. Y. Kekenusa. J.S. Hatidja. D. (2012). Analisis Jalur Faktor-Faktor Penyebab Kriminalitas Di Kota Manado. Jurnal Ilmiah Sains. Vol. 12(2).

Mastuti. E. (2005). Analisis Faktor Alat Ukur Kepribadian Big Five (Adaptasi Dari Ipip) Pada Mahasiswa Suku Jawa. Insan. $7(3)$.

Mosaku. S.K, Akinsulore. A, Onwuchekwa. I. (2013). Personality Traits Among Inmates of Aba Prison in Nigeria: Influence of The Five Factor Model On Inmate Status and Type of Offences. Nigerian Journal of Psychiatry. 12(2). Nigerian.

Nur'artavia. M.R. (2017). Karakteristik Pelajara Penyalahguna Napza Dan Jenis Napza Yang Digunakan Di Kota Surabaya. Surabaya: Universitas Airlangga. 12(1). Hal 27-38.

Pasiza. R. Nugroho. S, dan Faisal. F. (2014). Analisis Jalur FaktorFaktor Penyebab Kriminalitas Di Indonesia. Universitas Islam Bengkulu.

128 | Journal An-nafs: Vol. 4 No. 2 Desember 2019 
Tania Mayendry, Dkk | Kepribadian Narapidana

Poulose. V.T. (2006). Theories of Crime. Department of Philosophy: University of Calicut.

Ramdhani. N. (2012). Adaptasi Bahasa Dan Budaya Inventori Big Five. Jurnal Psikologi. 39(2). Hal 189-207.

Rocque. M., Posick. C., Hoyle. J. (2015). Age and Crime. Georgia Southern University.

Sudirohusodo. M. (2002). Pelaksanaan Pembinaan Narapidana Di Lembaga Pemasyarakatan Magelang. Yogyakarta.

Suharsoyo. A., Surbaktto. N., \& Azhari. A.F. (2014). Tipologi Kejahatan Pencurian Studi Tentang Karakter Pelaku Tindak Pindana Pencurian Periode Tahun 2011-2013 Di Kabupaten Sukoharjo. 